NBER WORKING PAPER SERIES

\title{
WHAT EXPLAINS THE FLOW OF FOREIGN FIGHTERS TO ISIS?
}

\author{
Efraim Benmelech \\ Esteban F. Klor \\ Working Paper 22190 \\ http://www.nber.org/papers/w22190
NATIONAL BUREAU OF ECONOMIC RESEARCH
1050 Massachusetts Avenue
Cambridge, MA 02138
April 2016

We thank Lauran Cohen, Michael Freedman, Laura Jones Dooley, David Matsa and Paola Sapienza for very helpful comments. Jimmy Hong provided excellent research assistance. All errors are our own. The views expressed herein are those of the authors and do not necessarily reflect the views of the National Bureau of Economic Research.

NBER working papers are circulated for discussion and comment purposes. They have not been peer-reviewed or been subject to the review by the NBER Board of Directors that accompanies official NBER publications.

(C) 2016 by Efraim Benmelech and Esteban F. Klor. All rights reserved. Short sections of text, not to exceed two paragraphs, may be quoted without explicit permission provided that full credit, including $(\subset$ notice, is given to the source. 
What Explains the Flow of Foreign Fighters to ISIS?

Efraim Benmelech and Esteban F. Klor

NBER Working Paper No. 22190

April 2016

JEL No. H0,H56,K42,O52,O53

\begin{abstract}
This paper provides the first systematic analysis of the link between economic, political, and social conditions and the global phenomenon of ISIS foreign fighters. We find that poor economic conditions do not drive participation in ISIS. In contrast, the number of ISIS foreign fighters is positively correlated with a country's GDP per capita and Human Development Index (HDI). In fact, many foreign fighters originate from countries with high levels of economic development, low income inequality, and highly developed political institutions. Other factors that explain the number of ISIS foreign fighters are the size of a country's Muslim population and its ethnic homogeneity. Although we cannot directly determine why people join ISIS, our results suggest that the flow of foreign fighters to ISIS is driven not by economic or political conditions but rather by ideology and the difficulty of assimilation into homogeneous Western countries.
\end{abstract}

\author{
Efraim Benmelech \\ Kellogg School of Management \\ Northwestern University \\ 2001 Sheridan Road \\ Evanston, IL 60208 \\ and NBER \\ e-benmelech@kellogg.northwestern.edu \\ Esteban F. Klor \\ Deptartment of Economics \\ Hebrew University \\ Mount Scopus \\ Jerusalem ISRAEL 91905 \\ eklor@huji.ac.il
}




\section{Introduction}

About 30,000 fighters from at least 85 countries have joined the Islamic State of Iraq and Syria (ISIS) as of December 2015. Although the great majority of ISIS recruits come from the Middle East and the Arab world, many foreign fighters also come from Western nations, including most members of the European Union, as well as the United States, Canada, Australia, and New Zealand. Thousands of fighters from Russia and hundreds from Indonesia and Tajikistan have also joined ISIS. The recruitment of foreign fighters to join ISIS is a global phenomenon. ${ }^{1}$

Because of the threat ISIS poses to other nations, it is critical to understand the factors that lead foreigners to join this Islamic jihadist state. Foreign recruits represent a threat to the international community for a number of reasons. After joining ISIS, they engage in combat in Syria and Iraq against ISIS enemies. They also can easily return home from combat largely unnoticed on their government-issued passports. As returnees trained in terrorist tactics and furnished with new connections, these fighters can create terror networks to commit attacks at home (Hegghammer, 2013). For example, Abdelhamid Abaaoud, the alleged leader of the cell that committed the Paris attacks in November 2015, visited Syria, returned radicalized, and recruited an extensive network of accomplices to conduct the attacks (The Guardian, November 18, 2015).

Foreign fighters also provide ISIS with the human capital needed to operate in foreign countries. Once in Syria or Iraq, they can recruit operatives and lead them to commit attacks in Western countries without even returning home. As FBI director James Comey stated (House Homeland Security Committee Hearing, September 2014),

Foreign fighters traveling to Syria or Iraq could, for example, gain battlefield experience and increased exposure to violent extremist elements ... they may use these skills and exposure to radical ideology to return to their countries of origin, including the United States, to conduct attacks on the Homeland.

The extreme gravity of this phenomenon leads us to ask: Why do people from all over the world join ISIS? We provide the first systematic analysis of the link between economic, political, and social conditions with the global phenomenon of ISIS foreign fighters. We combine a detailed data set on the number of ISIS foreign fighters emerging from countries around the world with data on

\footnotetext{
${ }^{1}$ The only country in the Middle East for which there are no records of ISIS foreign fighters is Cyprus.
} 
countries' social, political, and economic indicators. These indicators capture individual countries? political freedom, social fragmentation, economic development, inequality, and unemployment.

We find that poor economic conditions do not drive participation in ISIS. In contrast, the number of ISIS foreign fighters is positively correlated with a country's GDP per capita and its Human Development Index (HDI). In fact, many foreign fighters originate from countries with high levels of economic development, low income inequality, and highly developed political institutions. Other factors that explain the number of ISIS foreign fighters are the size of a country's Muslim population and the degree of its homogeneity. Interestingly, a country's political characteristics are not correlated with the number of ISIS fighters from that country. The results are robust for different empirical specifications, econometric models, and samples of countries.

The notion that social, economic, and political conditions may correlate with terrorism is not new. The widespread view among policy makers after the 9/11 attacks is that poverty breeds terrorism. This view is based largely on research into the economics of conflict, which suggest that political unrest is correlated with poor economic conditions. For example, Alesina et al. (1996) argue that poor economic conditions increase the likelihood of political coups, and Collier and Hoeffer (2004) and Miguel, Satyanath, and Sergenti (2004) show that poor economic conditions are correlated with civil wars.

A growing body of empirical literature either confirms a negative correlation between terrorism and economic prosperity [Abadie (2006); Benmelech, Berrebi, and Klor (2012)] or finds no correlation between the two [Krueger and Maleckova (2003); Drakos and Gofas (2006); Piazza (2006); Krueger and Laitin (2008)]. To our knowledge, our study is the first to find a robust positive correlation between GDP per capita, HDI, and volunteering into an insurgent army. It even contrasts with a similar analysis by Krueger (2006) that focuses on foreign fighters captured in Iraq in 2005. As in our study, Krueger (2006) finds that countries with a large Muslim population are more likely to have more of their citizens join the Iraqi insurgency. Contrary to our findings, however, Krueger (2006) reports that low levels of civil liberties or political rights are associated with a larger number of foreign fighters captured in Iraq, and he finds no correlation between the number of fighters and GDP per capita.

Our results indicate that foreign recruits into terror organizations come from a new type of country: they come largely from prosperous, ethnically and linguistically homogenous countries. We believe that this novel finding is explained by the willingness of individuals to volunteer into ISIS 
(the supply of foreign fighters) and by ISIS recruitment strategy (the demand for foreign fighters). As much of the previous literature states, most recruits are driven by religious and political ideology. Our analysis suggests that the more homogenous the host country is, the more difficulties Muslim immigrants experience in their process of assimilation. This induces some of them to radicalization (Gould and Klor, 2016). On the demand side, it is documented that ISIS targets recruits from prosperous Western countries (Weiss and Hassan, 2014). These recruits bring to ISIS all the benefits mentioned above. ISIS lures this target audience by preying on impressionable youth through its sophisticated propaganda machine and use of social media.

The rest of the paper is organized as follows. Section 2 describes the data used in the paper and presents the summary statistics. Section 3 contains the empirical analysis of the determinants of ISIS foreign fighters. Section 4 concludes.

\section{Data and Summary Statistics}

The main data set used here comes from two reports issued by the Soufan Group, which provides strategic security intelligence to governments and multinational organizations. The first report, Foreign Fighters in Syria, by Richard Barrett, was published in June 2014 (Barrett, 2014). This report calculates the number of ISIS foreign fighters from each country using official estimates of the number of citizens and residents of each country who have traveled to fight in Syria. According to Barrett (2014, p. 11), the figures are based generally on information gathered from social media, community sources, or investigations. Because ISIS prefers to conceal the identity of its members, it is likely that the reported numbers underestimate the actual number of recruits. As Barrett (2014, p. 12) writes:

It is only when someone dies that his family learns that he went to Syria, either through a telephone call from a friend designated by the dead fighter for that purpose, or through a death notice published on a group's website, Facebook page or Twitter feed.

Barrett (2014) provides estimates of the number of citizens or residents who have joined ISIS and have traveled to fight in Syria for 25 countries. He also lists 57 countries from which citizens or residents are reported to have joined ISIS and traveled to fight in Syria but for which no official count exists.

A report by the Soufan Group updates the numbers in Barrett (2014). This report, titled 
Foreign Fighters: An Updated Assessment of the Flow of Foreign Fighters into Syria and Iraq (Soufan Group, 2015), was released in December 2015. In addition to providing data on 65 countries of the number of citizens or residents who have joined ISIS and have traveled to fight in Syria and Iraq, the report lists 20 nations from which citizens or residents are reported to have joined ISIS and traveled to fight in Syria but for which no official or unofficial count exists.

\subsection{Ranking of ISIS Foreign Fighters by Country}

Table 1 ranks countries based on the number of its citizens or residents who have become ISIS fighters. The information is based on data in Soufan Group (2015). For each country, the official count of ISIS foreign fighters is listed along with unofficial estimates when available. As the table demonstrates, Tunisia has the highest number of ISIS foreign fighters $(6,000)$, followed by Saudi Arabia $(2,500)$, Russia $(2,400)$, Turkey $(2,100)$, and Jordan $(2,000)$. Among countries in Western Europe, France has the highest number of ISIS foreign fighters $(1,700)$, followed by Germany $(760)$, the United Kingdom (760), and Belgium (470). Cambodia, Moldova, Romania, and South Africa have only one ISIS foreign fighter each.

Table 2 provides information on the 15 countries for which there are only unofficial counts (Soufan Group, 2015). According to unofficial data, there are 600 ISIS foreign fighters from Libya, followed by 500 from Kyrgyzstan, and 360 from Turkmenistan. Kuwait and Somalia have 70 ISIS fighters each, followed by Serbia with 60, and Afghanistan, Georgia, and Trinidad and Tobago with 50 each. $^{2}$ Table 3 lists the 20 countries for which there are indications that citizens or residents have left to join ISIS and fight in Syria or Iraq but no official or unofficial count exists.

Next, we calculate the number of ISIS foreign fighters per million by dividing the number of ISIS fighters from each country by the country's population (in millions), using data from the World Bank. We use the official count of foreign fighters for countries when this figure is available (Table 1). Otherwise, we use the unofficial count presented in Table 2. Table 4 shows the populationbased ranking of ISIS fighters. Tunisia ranks first in the number of ISIS foreign fighters to overall population, with 545.5 ISIS fighters per million individuals, followed by the Maldives (500 per million), Jordan (303 per million), and Lebanon (200 per million). Among Western European countries, Belgium ranks first (42 per million), followed by Austria (35.3 per million), Sweden (30.9

\footnotetext{
${ }^{2}$ In cases in which either the official or the unofficial count is reported as a range in the report by The Soufan Group (2015) we use the mid-range point as the count number.
} 
per million), and France (25.7 per million).

Table 5 shows the number of ISIS foreign fighters relative to the Muslim population in each country (in millions). ${ }^{3}$ As the table illustrates, Finland has the largest number of ISIS foreign fighters relative to the size of its Muslim population, followed by Ireland, Belgium, Sweden, and Austria. This table already suggests that inequality and poverty are unlikely to be root causes of recruits joining ISIS. After all, Finland's GDP per capita in 2010 was equal to $\$ 46,205$, and it has a Gini coefficient of 27.1, which makes it not only one of the wealthiest countries in the world but also the 11th most egalitarian. Likewise Norway, which ranks fourth worldwide in terms of equality and in the top fifth percentile in GDP per capita, is in the top ten countries with the most ISIS fighters relative to its Muslim population. Belgium and Sweden, which rank third and fourth in the number of ISIS fighters in Table 5, are respectively the 12th and 15th most egalitarian countries in the world.

\subsection{Summary Statistics}

Table 6 presents descriptive statistics for the number of foreign fighters and the social, economic, and political indicators used in the empirical analysis. It reports mean, 25th, and 75 th percentiles along with the median, the standard deviation, the minimum and maximum, and the number of observations for each variable.

The mean number of ISIS foreign fighters is 164.29 , with a standard deviation of 594.78. In calculating the number of ISIS fighters, we omit the countries reported in Table 3 , given that information on their number of foreign fighters is unavailable. Next, we define a dummy variable that takes the value of 1 for countries with at least one ISIS fighter (including countries listed in Table 3), and zero otherwise. As Table 6 shows, $43.5 \%$ of countries have a positive number of ISIS fighters who have traveled to fight in Syria and Iraq. ${ }^{4}$ The mean population of countries in the sample is 36.74 million individuals, with an average Muslim population of $24.2 \%$ and a median of $2.7 \%$.

We use the World Bank's GDP per capita (in current US prices, 2010) as our first measure of economic development. The GDP per capita in 2010 ranges from $\$ 214$ to $\$ 145,221$ with a mean (median) of $\$ 14,404(\$ 5,056)$. We also use the United Nations Human Development Index (HDI)

\footnotetext{
${ }^{3}$ The data on Muslim populations are as of 2010 and were obtained from the Pew Research Center, a nonpartisan American think tank that provides information on social issues, public opinion, and demographic trends.

${ }^{4}$ Given that the analysis in this paper focuses on foreign fighters we exclude Iraq and Syria from the sample.
} 
from 2010 as an alternative measure of economic development. The HDI measures the well-being of the residents of a country based on three different dimensions: education, health, and income. This measure is constructed using country data on life expectancy at birth, school enrollment ratio, adult literacy, and GDP per capita. The index has a potential range of zero to 1 , though the actual minimum is 0.326 (Niger) and the maximum is 0.94 (Norway). As a measure of income inequality, we focus on the Gini Index, which is available from the World Bank database for 151 countries. The Gini Index ranges from a minimum of 16.6 (Azerbaijan) to a maximum of 63.4 (South Africa), with a mean of 39.36. Our final economic measure is unemployment. The unemployment rate across the 164 countries for which data are available in 2010 is on average $8.61 \%$, with a 25th percentile of $4.65 \%$ and a 75 th percentile of $10.50 \%$.

As our measure of political freedom, we use Freedom House's Political Rights for the year 2010. The Political Rights Index ranges from 1 to 7, with high values representing the absence of political rights. Table 6 shows that at least $25 \%$ of the countries in our sample are full democracies with a political rights index equal to 1 .

We also include in our analysis indices for ethnic, linguistic, and religious fractionalization. These indices were built in Alesina et al. (2003) and have been updated every year since by the Quality of Government Institute at the University of Gothenburg. The indices calculate the probability that two randomly selected individuals from a given country will not share the same ethnicity, language, and religion. As with all previous measures, the indices show a great deal of variation among the countries in our sample. Korea, Japan, and Portugal are examples of countries with very low ethnic and linguistic fractionalization, whereas African countries (for example, Cameroon, Kenya, and Liberia) show high levels of ethnic and linguistic fractionalization. Muslim countries tend to have low levels of religious fractionalization (for example, Algeria, Morocco, and Turkey are all below 0.01), whereas Australia, the United States, and South Africa are the three countries with the highest levels of religious fractionalization (their levels are $0.821,0.824$, and 0.86 , respectively).

Last, we collect information on the distance in kilometers between each of the countries and Syria. The mean distance is 6,265.9 kilometers and ranges from a minimum of 84 kilometers to a maximum of 16,651 kilometers. 


\section{Empirical Analysis}

\subsection{Determinants of ISIS Foreign Fighters}

Before we move into the systematic analysis of the determinants of ISIS foreign fighters, we provide a preview of the main correlations of interest in Figures 1 and 2. Figure 1 presents scatter plots (together with the estimated linear fit) of the economic indices used in the analysis with the number of ISIS foreign fighters normalized by each country's Muslim population. Figure 2 presents similar scatter plots but focuses on the Political Rights Index and the available indices of fractionalization. Only countries with a positive number of ISIS foreign fighters are included in the plots.

Figure 1 shows that the number of ISIS foreign fighters per Muslim residents is (i) positively correlated with GDP per capita and with HDI, the available measures of economic prosperity; (ii) negatively correlated with economic inequality; and (iii) not highly correlated with unemployment. These findings directly contradict the recent assertions of Thomas Piketty, the prominent scholar of income inequality. In an op-ed published in Le Monde in the aftermath of the recent Paris terror attacks, Piketty (2015) claims that "only an equitable model for social development will overcome hatred." The large number of foreign fighters coming from highly equitable and wealthy countries like Finland, Belgium, and Sweden (see Table 5) and the correlations shown in Figure 1 run contrary to those claims.

Figure 2 presents a similar picture regarding the Political Rights Index and the factionalization indices. The figure shows that most ISIS foreign fighters come from established democracies at the top of the scale on political rights. It is also evident that societies with lower levels of ethnic and linguistic fractionalization contribute more foreign fighters to ISIS per number of Muslim residents.

We turn next to the regression analysis, in which we use different empirical models to estimate the determinants of the flows of ISIS foreign fighters to Iraq and Syria. Table 7 reports results from a probit regression estimating the probability that at least one foreign fighter from a given country joins ISIS. We define a dummy variable that takes the value of 1 for all countries in Tables 1,2 , and 3 , and zero otherwise. We use the dummy variable as our dependent variable in the regression analysis reported in Table 7 .

In Column (1) of Table 7 we focus exclusively on the economic determinants of joining ISIS. We add to our model political and social variables in Column (2), and we include continent fixed effects in Column (3). As an overall measure of the country's level of development we use the log of 
GDP per capita in the year 2010 in the first three columns of the table. In Column (4) we use an alternative measure of development instead of GDP per capita - the Human Development Index - a composite statistic of life expectancy, education, and income per capita indicators, which are used to rank countries into four tiers of human development. In Column (5) we focus on the Gini Index as a measure of income inequality.

As Table 7 demonstrates, a country's population size and the size of its Muslim population are significant determinants of the number of ISIS foreign fighters originating from the country. According to the estimated coefficients, a $10 \%$ increase in the size of the Muslim population (relative to its mean) increases the likelihood that there will be at least one ISIS foreign fighter by 1.2 percentage points.

As the first three columns of the table show, GDP per capita and the likelihood that at least one fighter from a given country joins ISIS are highly positively correlated. The coefficient is also of a substantial magnitude: A 10\% increase in GDP per capita is associated with an increase of 1.5 percentage points in the likelihood that citizens and residents of the country end up joining ISIS.

Similar to the positive association between GDP per capita and the likelihood of joining ISIS, we find in Column (4) that an alternative measure of development - the Human Development Index - is also positively correlated with the likelihood of joining ISIS. We turn next to analyze the impact of the income inequality on the probability that an individual from the country joins ISIS. Interestingly, Column (5) of Table 7 demonstrates that the marginal effect of the Gini Index of income inequality is negative (though not precisely estimated). In contrast to the assertions made by Piketty (2015), we do not find that an increase in income inequality is associated with an increase in the likelihood of joining ISIS. Moreover, we find a positive correlation between unemployment and ISIS foreign fighters - although, as we show in our robustness tests Tables, this correlation is driven entirely by Muslim countries.

Moving to the political variables, we conjecture that the inability of individuals to participate freely in the political process and exercise freedom of expression and belief may lead to radicalization and increase the likelihood of joining ISIS. Yet, as Columns (2) through (5) of Table 7 show, we find that a country's political characteristics are not correlated with the propensity to join ISIS.

In unreported results we focus exclusively on countries whose Muslim population is less than one third of their total population. When we run the regressions using the subsample of non-Muslim countries, we obtain results that are almost identical to those reported in Table 7 with the full 
set of countries. The only difference between the results is that unemployment is not a significant determinant of the likelihood of joining ISIS in non-Muslim countries. That is, we observe a positive correlation between indicators of economic prosperity and the likelihood of joining ISIS, whereas income inequality, unemployment, and social and political conditions are not determinants of joining ISIS in non-Muslim countries.

\subsection{Robustness Tests}

In this subsection we test the robustness of the baseline findings reported in Table 7 to alternative estimations and model specifications. In Table 8 we conduct similar analysis to Table 7 using the $\log$ of the number of ISIS fighters from each country as the dependent variable. We use the group of countries for which the number of ISIS foreign fighters is known either officially or non-officially (Tables 1 and 2), as well as all countries for which there are no ISIS foreign fighters - that is, all the other countries in the world excluding those countries in Table 3, resulting in 143 countries. $^{5}$ We set the number of ISIS foreign fighters at zero for all countries that are not listed in Tables 1 , 2, and, 3, and the dependent variable is defined as the log of (1+Number of ISIS fighters).

The results in Table 8 are generally similar to those documented in Table 7 . As Table 8 shows, the main determinants of the number of ISIS foreign fighters are the size of the country's Muslim population, its economic prosperity - measured by either GDP per capita or HDI - and its ethnic fractionalization. ${ }^{6}$

We estimate regressions for all countries (Columns (1) - (5)) as well as for only non-Muslim countries - countries whose Muslim population is less than one third of their total population - in Columns (6)-(8). As the table demonstrates, whereas general measures of economic development such as GDP per capita and HDI are positively correlated with the number of ISIS foreign fighters, unemployment is positively associated with the number of ISIS foreign fighters only in Muslim countries. Moreover, our measure of income inequality (Gini) is not correlated with the number of ISIS foreign fighters in either sample.

As Column (6) of Table 8 demonstrates, among non-Muslim countries, the elasticities of ISIS foreign fighters to the Muslim population and GDP per capita are 0.384 and 0.507 , respectively.

\footnotetext{
${ }^{5}$ Countries in Table 3 are countries with ISIS foreign fighters but for which official or non-official counts are not available.

${ }^{6}$ The three available measures of fractionalization are highly correlated. Hence, from Table 8 onwards we include only ethnic fractionalization in the empirical models to avoid concerns related to multicollinearity. We obtain the same results if we include either of the other two available measures of fractionalization.
} 
That is, an increase of $10 \%$ in the size of the Muslim population is associated with an increase of $3.8 \%$ in the number of ISIS foreign fighters, and an increase of $10 \%$ in GDP per capita is associated with an increase of $5.1 \%$ in the number of ISIS foreign fighters. This column also shows that ethnic fractionalization is highly negatively correlated with the number of ISIS foreign fighters - implying that these fighters tend to come from more ethnically homogenous societies.

Whereas in Table 7 we studied the "extensive margin" of ISIS foreign fighters, Table 9 focuses on the "intensive margin." That is, conditional on a country having at least one ISIS foreign fighter, how do different variables affect the number of ISIS foreign fighters from a particular country? For this purpose, Table 9 further restricts the sample by looking only at countries with both an official or a non-official count of ISIS foreign fighters and, according to these data, with at least one foreign fighter. We use the official count whenever it is available (the countries listed in Table 1) and the non-official count when an official count does not exist (the list of countries in Table 2), and we define the dependent variable as the log of the number of ISIS fighters.

Count data, official or non-official, exists for 65 countries. Given that data on the explanatory variables does not exist for every country - the final sample that is used in the regression in the first column includes 61 countries with non-zero count data. Of course, this limits the available variation in the data, especially when we also control for continent fixed effects. As before, we include all countries with available information in Columns (1)-(5) and non-Muslim countries in Columns (6)-(8).

As Table 9 illustrates, the elasticity of the number of ISIS fighters to the size of the country's Muslim population is significant at the $1 \%$ level and is between 0.718 and 1.110 . That is, a $10 \%$ increase in the size of the Muslim population is associated with between seven and $10 \%$ increase in the number of ISIS foreign fighters. Although the smaller sample size does not allow us to estimate the coefficients on the economic and social variables with sufficient precision, their sign and magnitudes are in line with those estimated in Table 8. The estimates in Table 9 confirm the conclusion from the previous tables that dire economic conditions are not root causes of participation in ISIS operation in Iraq and Syria.

We next analyze the link between the number of ISIS foreign fighters and economic conditions using a count data model because the dependent variable is a nonnegative integer, and we report the results in Table 10. One common feature of count data (which also holds in the ISIS foreign fighters data) is that the conditional variance is higher than the conditional mean - that is, the 
data exhibit overdispersion. Given the overdispersion in the number of ISIS foreign fighters, we use a negative binomial model to estimate the effects of economic, political, and social conditions on the number of foreign fighters in each country.

Consistent with the previous analyses, Table 10 also shows that (i) there exists a positive and highly significant correlation between the number of ISIS foreign fighters and the size of the local Muslim population; (ii) the number of ISIS foreign fighters and economic development (measured by either GDP per capita or HDI) are positively correlated; and (iii) there is a negative correlation between social fractionalization and the number of ISIS foreign fighters. Interestingly, our negative binomial estimates suggest not only that income inequality does not lead to more participation in ISIS but, in fact, that income inequality exhibits a significant negative correlation with the number of ISIS foreign fighters. That is, controlling for other socioeconomic variables, income inequality is associated with fewer - not more - ISIS foreign fighters.

\section{Conclusion}

Using data on the number of ISIS foreign fighters from around the world, we provide a systematic analysis of the link between economic, political, and social conditions and the global phenomenon of ISIS foreign fighters. Our results show that, in contrast to conjectures made recently by economists and policy makers, economic conditions are not the root causes of the global phenomenon of ISIS foreign fighters. In fact, many foreign fighters originate from countries with high levels of economic development, low income inequality, and highly developed political institutions.

If poverty and lack of social equality are not to blame, then why are Western European countries disproportionately significant sources of ISIS foreign fighters? The reason lies in other country characteristics: they are ethnically and linguistically homogenous. In fact, the more homogenous the host country is, the greater difficulty immigrants such as Muslims from the Middle East experience in assimilating. As other research has shown, isolation induces some of them to become radicalized. 


\section{References}

Abadie, Alberto. 2006. "Poverty, Political Freedom and the Roots of Terrorism," American Economic Review, 96 (2): 50-56.

Alesina, Alberto, Arnaud Devleeschauwer, William Easterly, Sergio Kurlat and Romain Wacziarg. 2003. "Fractionalization," Journal of Economic Growth, 8 (2): 155-194.

Alesina, Alberto, Sule Ozler, Nouriel Roubini and Philip Swagel. 1996. "Political Instability and Economic Growth," Journal of Economic Growth, 1 (2): 189-211.

Barrett, Richard. 2014. "Foreign Fighters in Syria," The Soufan Group.

Benmelech, Efraim, Claude Berrebi and Esteban F. Klor. 2012. "Economic Conditions and the Quality of Suicide Terrorist," Journal of Politics, 74 (1): 113-128.

Bergen, Peter, Courtney Schuster and David Sterman. 2015. "ISIS in the West: The New Faces of Extremism," New America, Policy Paper, November 2015.

Collier, Paul and Anke Hoeffler. 2004. "Greed and Grievance in Civil War," Oxford Economic Papers, 56 (4): 563-595.

Gould, Eric and Esteban F. Klor. 2016. "The Long-Run Effect of 9/11: Terrorism, Backlash, and the Assimilation of Muslim Immigrants in the West," Economic Journal, forthcoming.

Halliday, Josh, and Jonathan Bucks. 2015. "Abdelhamid Abaaoud: What We Know about the Paris Attacks 'Mastermind' Guardian, 18 November.

Hegghammer, Thomas. 2013. "Should I Stay or Should I Go? Explaining Variation in Western Jihadists' Choice between Domestic and Foreign Fighting," American Political Science Review, 107 (1): $1-15$.

Krueger, Alan B. 2006. "The National Origins of Foreign Fighters in Iraq," Unpublished Manuscript, Princeton University.

Krueger, Alan B. 2007. What Makes a Terrorist: Economics and the Roots of Terrorism, Princeton, NJ: Princeton University Press.

Krueger, Alan B. 2008. "What Makes a Homegrown Terrorist? Human Capital and Participation in Domestic Islamic Terrorists Groups in the U.S.A," Economics Letters, 101 (3): 293-296. 
Krueger, Alan B. and David Laitin. 2008. "Kto Kogo? A Cross-Country Study of the Origins and Targets of Terrorism," in Terrorism, Economic Development, and Political Openness, Philip Keefer and Norman Loayza (eds.). New York, Cambridge University Press.

Krueger, Alan B. and Jitka Maleckova. 2003. "Education, Poverty and Terrorism: Is There a Casual Connection?" Journal of Economic Perspectives, 17 (4): 119-144.

Miguel, Edward, Shanker Satyanath and Ernest Sergenti. 2004. "Economic Shocks and Civil Conflict: An Instrumental Variables Approach," Journal of Political Economy, 112 (4): 725-753.

Piketty, Thomas. 2015. "Le Tout-Sécuritaire ne Suffira pas," Le Monde, November 24. Available at: http://piketty.blog.lemonde.fr/2015/11/24/le-tout-securitaire-ne-suffira-pas-2/.

Piazza, James A. 2006. "Rooted in Poverty?: Terrorism, Poor Economic Development, and Social Cleavages," Terrorism and Political Violence, 18 (1): 159-177.

Weiss, Michael and Hassan Hassan. 2015. ISIS: Inside the Army of Terror, New York: Regan Arts. 

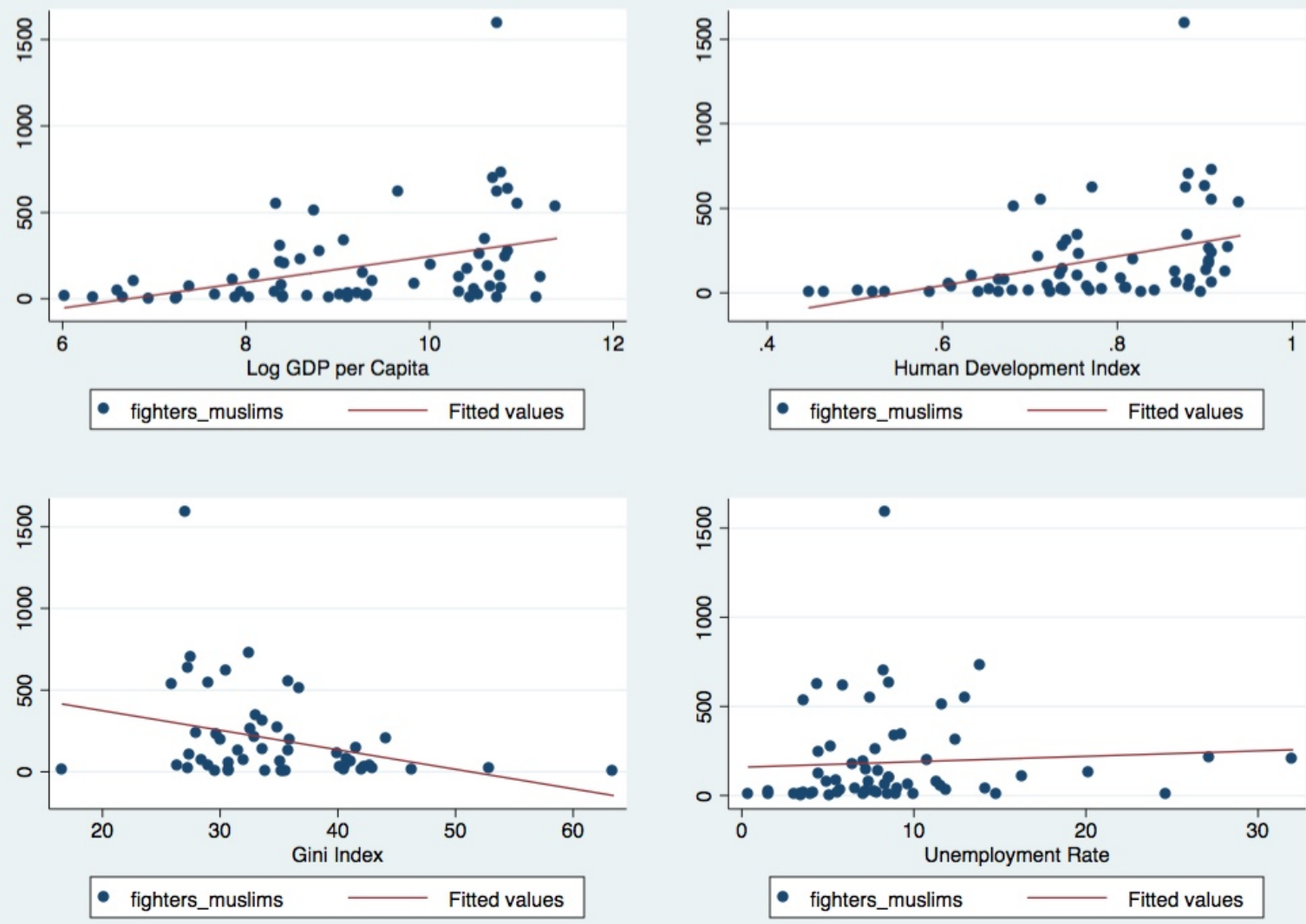

Figure 1: Correlation between Number of ISIS Foreign Fighters (as Percentage of Muslim Population) and Economic Indices 

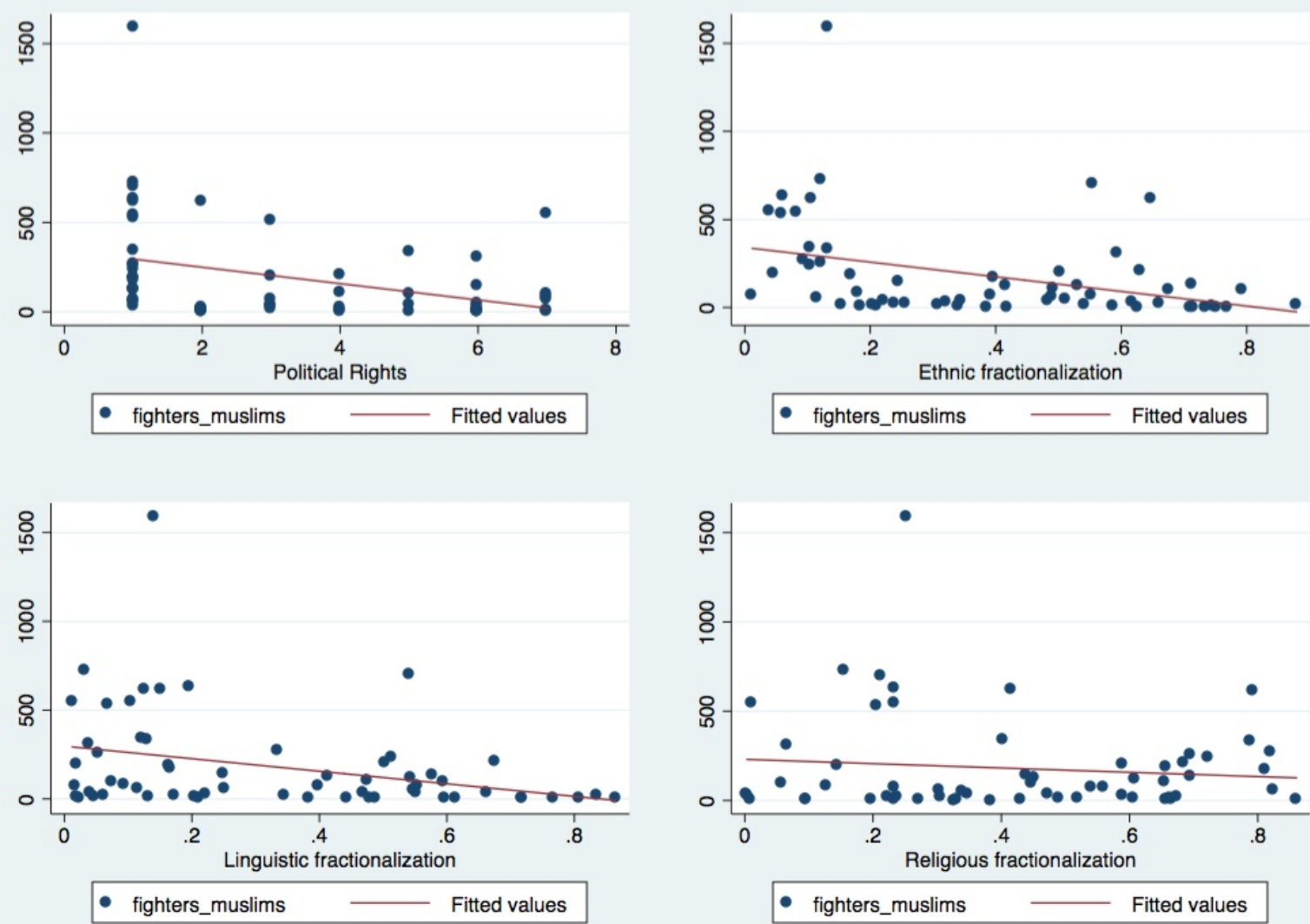

Figure 2: Correlation between Number of ISIS Foreign Fighters (as Percentage of Muslim Population) and Political Rights and Factionalization Indices 
Table 1:

Ranking of ISIS Foreign Fighters by Country Based on Official Count

\begin{tabular}{|c|c|c|c|c|c|c|c|}
\hline & \multicolumn{4}{|c|}{ Count } & \multicolumn{3}{|c|}{ Count } \\
\hline & Country & Official & Non-Official & & Country & Official & Non-Official \\
\hline 1. & Tunisia & 6,000 & 7,000 & 26. & Spain & 133 & 250 \\
\hline 2. & Saudi Arabia & 2,500 & . & 27. & Canada & 130 & . \\
\hline 3. & Russia & 2,400 & . & 28. & Denmark & 125 & 125 \\
\hline 4. & Turkey & 2,100 & . & 29. & Australia & 120 & 255 \\
\hline 5. & Jordan & 2,000 & 2,500 & 30. & Azerbaijan & 104 & 216 \\
\hline 6. & France & 1,700 & 2,500 & 31. & Malaysia & 100 & . \\
\hline 7. & Morocco & 1,200 & 1,500 & 32. & Philippines & 100 & . \\
\hline 8. & Lebanon & 900 & . & 33. & Albania & 90 & 150 \\
\hline 9. & Germany & 760 & . & 34. & Italy & 87 & . \\
\hline 10. & United Kingdom & 760 & . & 35. & Norway & 81 & 60 \\
\hline 11. & Indonesia & 700 & 500 & 36. & Finland & 70 & 85 \\
\hline 12. & Egypt & 600 & 1,000 & 37. & Pakistan & 70 & 330 \\
\hline 13. & Belgium & 470 & 470 & 38. & Sudan & 70 & 100 \\
\hline 14. & Tajikistan & 386 & . & 39. & Switzerland & 57 & . \\
\hline 15. & Bosnia & 330 & 217 & 40. & Israel & 50 & . \\
\hline 16. & Austria & 300 & 233 & 41. & Ireland & 30 & 30 \\
\hline 17. & China & 300 & . & 42. & India & 23 & 45 \\
\hline 18. & Kazakhstan & 300 & . & 43. & New Zealand & 7 & 6 \\
\hline 19. & Sweden & 300 & 300 & 44. & Brazil & 3 & . \\
\hline 20. & Kosovo & 232 & . & 45. & Madagascar & 3 & . \\
\hline 21. & Netherlands & 220 & 210 & 46. & Singapore & 2 & . \\
\hline 22. & Maldives & 200 & 60 & 47. & Cambodia & 1 & . \\
\hline 23. & Algeria & 170 & 225 & 48. & Moldova & 1 & . \\
\hline 24. & United States & 150 & 250 & 49. & Romania & 1 & . \\
\hline 25. & Macedonia & 146 & 100 & 50. & South Africa & 1 & . \\
\hline
\end{tabular}

Note: Based on data from Barrett (2014) and The Soufan Group (2015). 
Table 2:

Ranking of ISIS Foreign Fighters by Country without Official Count

\begin{tabular}{lcc}
\hline \hline & & \\
& Country & Non-Official Count \\
\hline 1. & Libya & 600 \\
2. & Kyrgyzstan & 500 \\
3. & Turkmenistan & 360 \\
4. & Kuwait & 70 \\
5. & Somalia & 70 \\
6. & Serbia & 60 \\
7. & Afghanistan & 50 \\
8. & Georgia & 50 \\
9. & Trinidad and Tobago & 50 \\
10. & Montenegro & 30 \\
11. & Argentina & 23 \\
12. & United Arab Emirates & 15 \\
13. & Portugal & 12 \\
14. & Qatar & 10 \\
15. & Japan & 9 \\
\hline \hline
\end{tabular}

Note: Based on data from Barrett (2014) and The Soufan Group (2015). 
Table 3:

Country with ISIS Foreign Fighters without Official or Non-official Counts

\begin{tabular}{lc}
\hline \hline & Country \\
\hline 1. & \\
2. & Armenia \\
3. & Bahrain \\
4. & Bangladesh \\
5. & Bulgaria \\
6. & Chad \\
7. & Côte d'Ivoire \\
8. & Czech Republic \\
9. & Eritrea \\
10. & Estonia \\
11. & Hungary \\
12. & Iran \\
13. & Luxembourg \\
14. & Mauritania \\
15. & Oman \\
16. & Palestine \\
17. & Poland \\
18. & Senegal \\
19. & Ukraine \\
20. & Uzbekistan \\
\hline \hline
\end{tabular}

Note: Based on data from Barrett (2014) and The Soufan Group (2015). 
Table 4:

Ranking of Countries based on ISIS Foreign Fighters to General Population

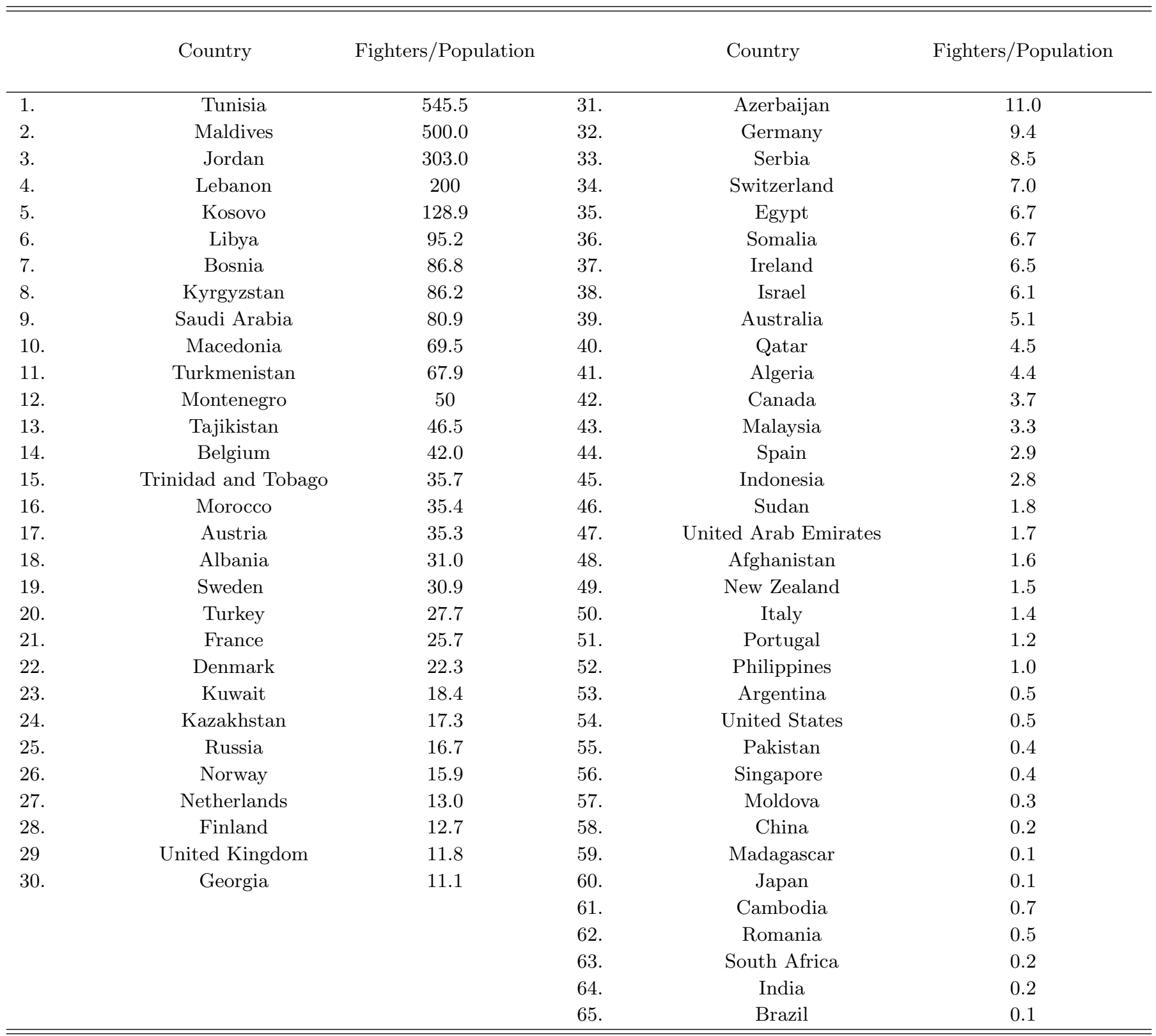

Note: Data on number of ISIS foreign fighters come from Barrett (2014) and The Soufan Group (2015). Population size data come from the World Bank. 
Table 5:

Ranking of Countries based on ISIS Foreign Fighters to Muslim Population

\begin{tabular}{|c|c|c|c|c|c|}
\hline & Country & Fighters/Muslims & & Country & Fighters/Muslims \\
\hline 1. & Finland & 1590.9 & 34. & Japan & 70.8 \\
\hline 2. & Ireland & 724.64 & 35. & Moldova & 69.4 \\
\hline 3. & Belgium & 699.4 & 36. & United States & 58.8 \\
\hline 4. & Sweden & 631.2 & 37. & Italy & 54.6 \\
\hline 5. & Austria & 619.2 & 38. & Tajikistan & 47.0 \\
\hline 6. & Trinidad and Tobago & 615.8 & 39. & Albania & 37.8 \\
\hline 7. & Tunisia & 546.6 & 40. & Morocco & 35.4 \\
\hline 8. & Denmark & 544.4 & 41. & Israel & 34.5 \\
\hline 9. & Norway & 529.4 & 42. & Kazakhstan & 30.8 \\
\hline 10. & Maldives & 508.1 & 43. & Turkey & 28.1 \\
\hline 11. & France & 342.4 & 44. & Argentina & 21.4 \\
\hline 12. & Lebanon & 335.0 & 45. & Kuwait & 21.3 \\
\hline 13. & Jordan & 306.7 & 46. & Philippines & 19.8 \\
\hline 14. & Montenegro & 270.3 & 47. & Romania & 16.8 \\
\hline 15. & Australia & 268.8 & 48. & Brazil & 14.6 \\
\hline 16 & United Kingdom & 256.2 & 49. & China & 12.2 \\
\hline 17. & Netherlands & 236.7 & 50 . & Madagascar & 11.6 \\
\hline 18. & Serbia & 228.4 & 51. & Azerbaijan & 11.1 \\
\hline 19. & Bosnia & 208.8 & 52. & Egypt & 7.1 \\
\hline 20. & Macedonia & 199.2 & 53. & Somalia & 6.8 \\
\hline 21. & Portugal & 192.3 & 54. & Qatar & 5.9 \\
\hline 22. & Germany & 187.9 & 55. & Malaysia & 5.5 \\
\hline 23. & New Zealand & 172.8 & 56. & Algeria & 4.5 \\
\hline 24. & Russia & 142.7 & 57. & Cambodia & 4.1 \\
\hline 25. & Kosovo & 140.6 & 58. & Indonesia & 3.1 \\
\hline 26. & Canada & 130.8 & 59. & Sudan & 2.5 \\
\hline 27. & Spain & 124.6 & 60. & Singapore & 2.4 \\
\hline 28. & Switzerland & 122.0 & 61. & United Arab Emirates & 2.2 \\
\hline 29. & Georgia & 105.8 & 62. & Afghanistan & 1.6 \\
\hline 30. & Libya & 98.6 & 63. & South Africa & 1.2 \\
\hline 31. & Kyrgyzstan & 97.1 & 64. & Pakistan & 0.4 \\
\hline 32. & Saudi Arabia & 83.3 & 65. & India & 0.1 \\
\hline 33. & Turkmenistan & 72.8 & & & \\
\hline
\end{tabular}

Note: Data on number of ISIS foreign fighters come from Barrett (2014) and The Soufan Group (2015). Data on the size of countries' Muslim population are from 2010 and come from the Pew Research Center. 
Table 6:

Summary Statistics

\begin{tabular}{|c|c|c|c|c|c|c|c|c|}
\hline & Mean & $\begin{array}{c}25 \text { th } \\
\text { Percentile }\end{array}$ & Median & $\begin{array}{c}75 \text { th } \\
\text { Percentile }\end{array}$ & $\begin{array}{l}\text { Standard } \\
\text { Deviation }\end{array}$ & Min & Max & Observations \\
\hline Population $_{2014}$ & 36.7 & 1.8 & 7.1 & 23.6 & 139.8 & 0.1 & $1,364.3$ & 193 \\
\hline$\%$ Muslims & $24.2 \%$ & $0.0 \%$ & $2.7 \%$ & $36.7 \%$ & $36.4 \%$ & $0.0 \%$ & $0.999 \%$ & 192 \\
\hline GDP per Capita2010 & $\$ 14,404$ & $\$ 1,419$ & $\$ 5,056$ & $\$ 15,901$ & $\$ 22,633$ & $\$ 214$ & $\$ 145,221$ & 193 \\
\hline Gini & 39.4 & 33.0 & 38.1 & 44.7 & 8.8 & 16.6 & 63.4 & 151 \\
\hline Unemployment & $8.61 \%$ & $4.7 \%$ & $7.6 \%$ & $10.5 \%$ & $5.71 \%$ & $0.4 \%$ & $32 \%$ & 164 \\
\hline Political Rights & 3.33 & 1 & 3 & 5 & 2.12 & 1 & 7 & 184 \\
\hline Ethnic Fractionalization & 0.44 & 0.2 & 0.43 & 0.67 & 0.26 & 0 & 0.93 & 179 \\
\hline Linguistic Fractionalization & 0.40 & 0.13 & 0.38 & 0.65 & 0.28 & 0.002 & 0.92 & 174 \\
\hline Religious Fractionalization & 0.44 & 0.23 & 0.46 & 0.65 & 0.23 & 0.002 & 0.86 & 182 \\
\hline
\end{tabular}

Note: This table provides summary statistics for the main variables used in the paper. See main body of the manuscript for a detailed description of data sources. 
Table 7:

The Likelihood of Joining ISIS: All Countries

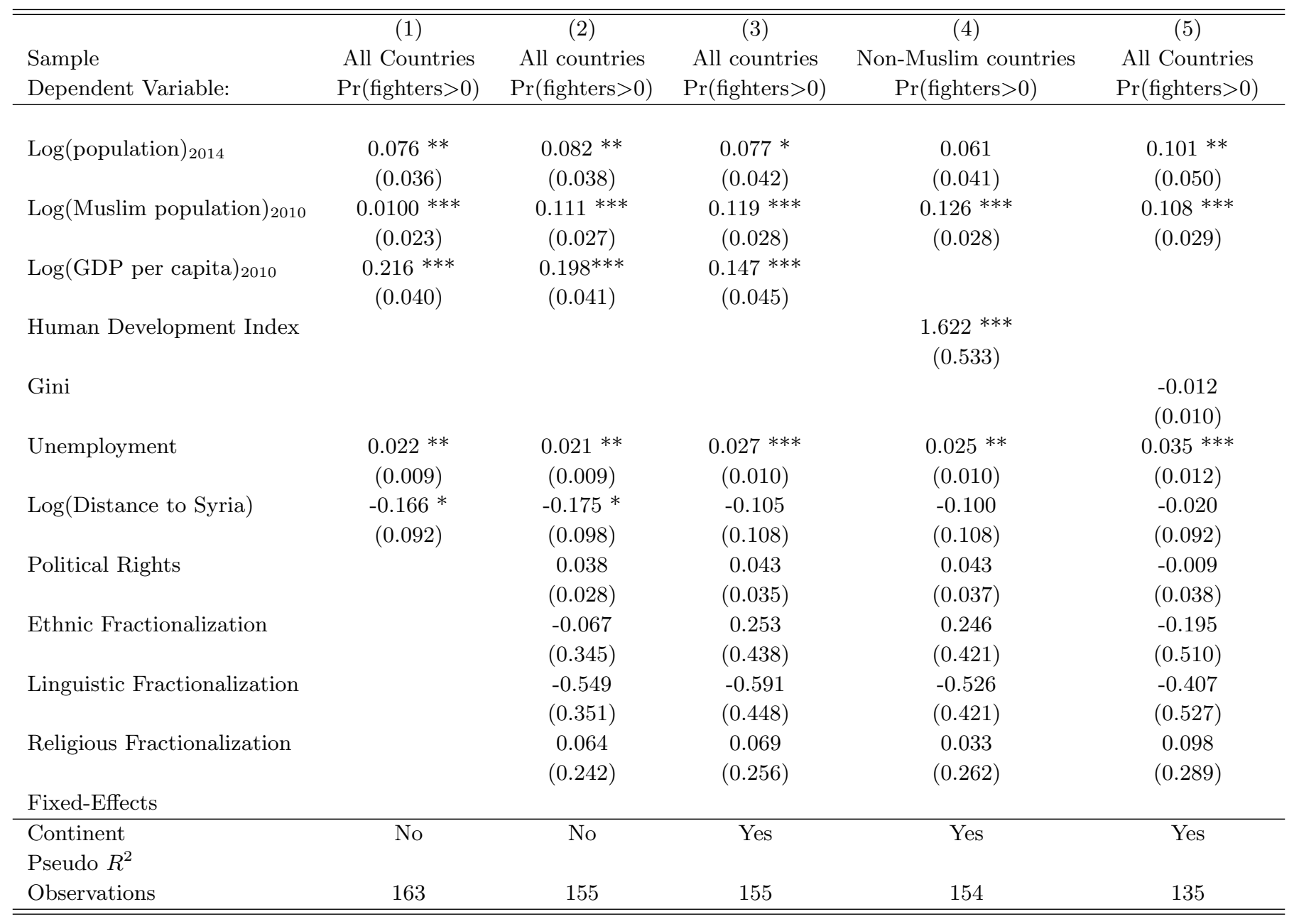

Note: The dependent variable is a dummy variable that takes the value of 1 if there is a positive number of ISIS foreign fighters, and zero otherwise. The table reports the marginal effects from a Probit regression computed at the means of the independent variables. Robust standard-errors appear in parentheses. *, **, and *** denote statistical significance at the $10 \%, 5 \%$, and $1 \%$ levels, respectively. 


\section{Table 8:}

\section{The Determinants of the Number of ISIS Foreign Fighters}

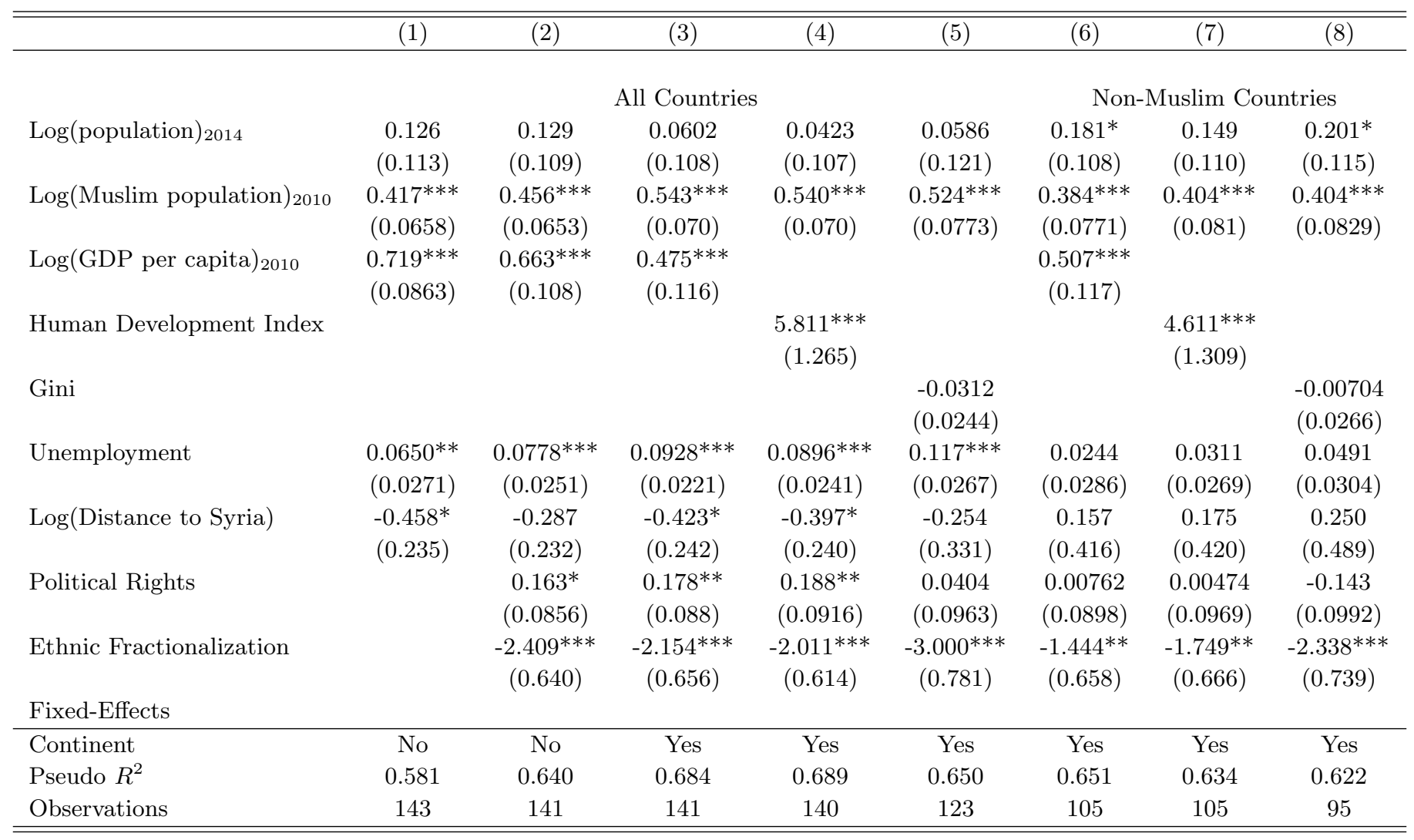

Note: The dependent variable is the log of (1+ number of ISIS foreign fighters). The reported coefficients are from OLS . regressions. Robust standard-errors appear in parentheses. * ${ }^{* *}$, and ${ }^{* * *}$ denote statistical significance at the $10 \%, 5 \%$, and $1 \%$ levels, respectively. 
Table 9:

The Determinants of the Number of ISIS Foreign Fighters: Intensive Margin

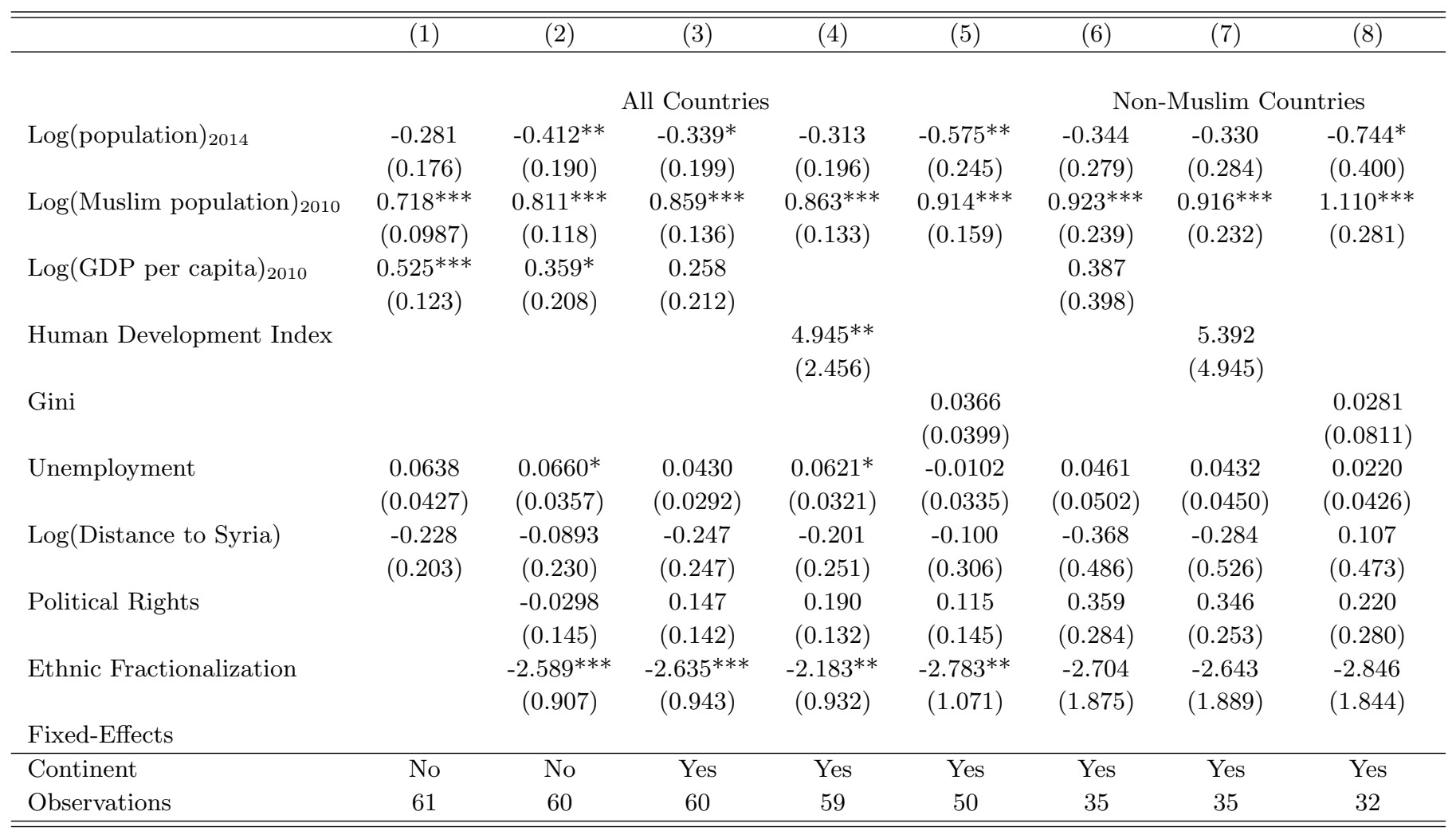

Note: The dependent variable is the log of number of ISIS foreign fighters. The reported coefficients are from OLS regressions. . Robust standard-errors appear in parentheses. *, **, and *** denote statistical significance at the $10 \%, 5 \%$, and $1 \%$ levels, respectively. 


\section{Negative Binomial Estimates of the Determinants of the Number of ISIS Foreign Fighters}

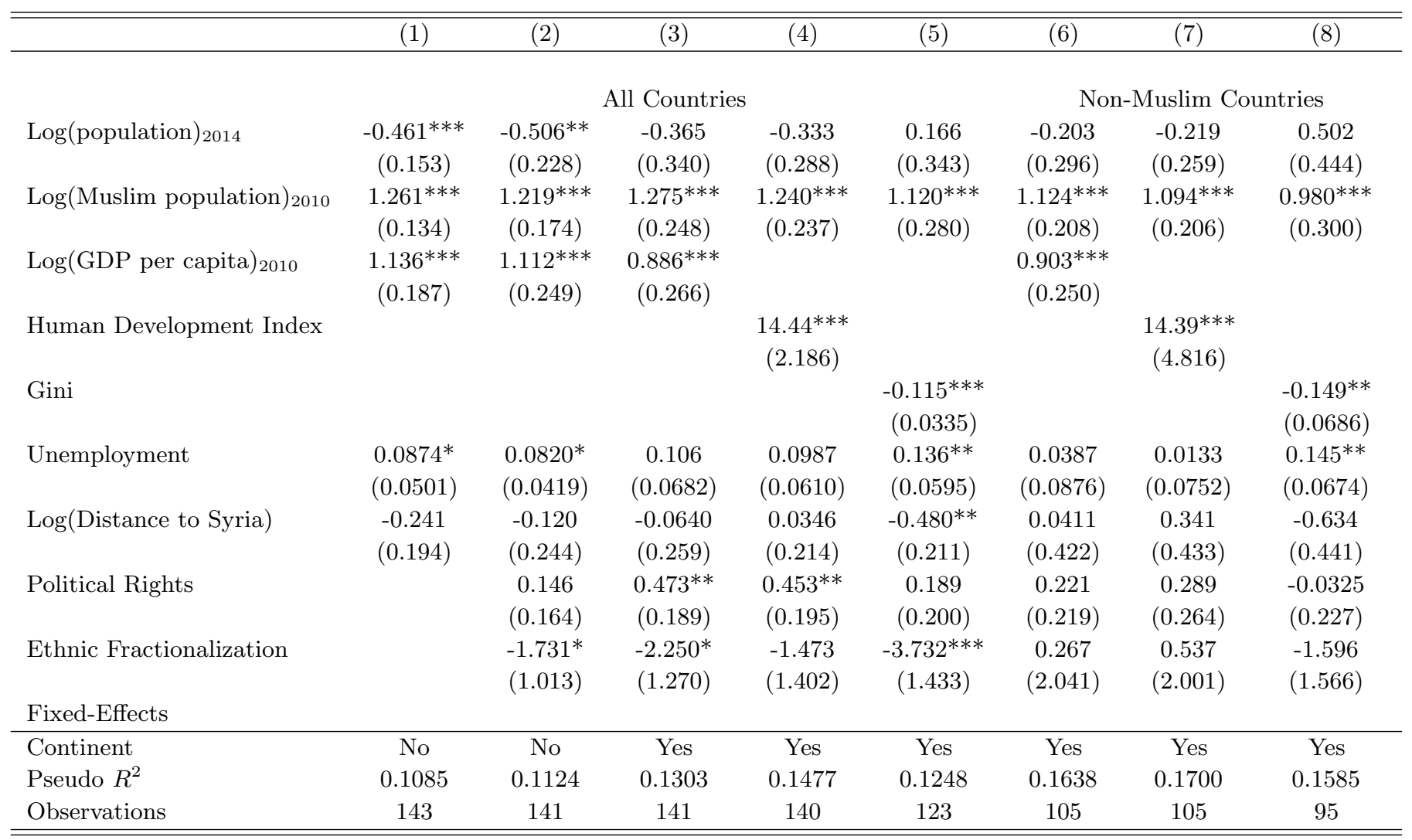

Note: The dependent variable is the number of ISIS foreign fighters. The reported coefficients are from negative binomial . regressions. Robust standard-errors appear in parentheses. * ${ }^{* *}$, and ${ }^{* * *}$ denote statistical significance at the $10 \%, 5 \%$, and $1 \%$ levels, respectively. 